\title{
Peningkatan Kemampuan Mengenal Lambang Bilangan 1-10 Melalui Penggunaan Media Buah Puzzle Angka Pada Kelompok A Di Raudlatul Athfal Babussalam, Krian, Sidoarjo
}

\author{
Alfiatul Izzati Irawan ${ }^{1}$
}

Received: 1405 2019/ Accepted: 0206 2019/ Published online: 15062019 (C) 2019 Early Chilhood Islamic Education Study Program

\begin{abstract}
This research was motivated by the ability to recognize symbols number 1-10 at low Raudlatul Athfal Babussalam. This is evidenced by student learning outcomes that show $78.26 \%$ of children do not know the symbol number 1-10 in the age range 4-5 years. This study aims to determine the learning process of recognizing the symbol numbers 1-10 in Group A at Raudlatul Athfal Babussalam, Krian, Sidoarjo by using Puzzle number media. As well as to find out the ability to recognize the symbol numbers 1-10 in Group A at Raudlatul Athfal Babussalam, Krian, Sidoarjo through the use of Puzzle numbers. The method used in this study is classroom action research with Kurt Lewin's model. This research was from Pre Cycle, Cycle I, Cycle II, and Cycle III. In Cycle I, Cycle II, and Cycle III consists of four stages, namely planning, action, observation, and reflection. The subjects of this study were students of Raudlatul Athfal Group A1 Age 4-5 years with 23 children. The research results are as follows: 1) Learning by using Puzzle fruit media numbers can run well in each cycle. This can be seen from the observations of teacher and student activities. The results of teacher activity in the first cycle reached $78.6 \%$, (enough) $83.4 \%$ cycle II (sufficient), and $92.8 \%$ (good) cycle III. While the results of observations of student activities in the first cycle reached $76.2 \%$ (enough), cycle II $83.4 \%$ (enough), and cycle III $94.04 \%$ (very good). 2) There is an increase in the ability to recognize the symbol number 1-10 after the use of media numbers Puzzle numbers. This can be seen from the results of children's learning completeness at the first cycle stage $39.2 \%$ (Not Developed) with an average of 50.35 (enough), cycle II results of 60.9\% (Starting to Grow) with the average learning outcomes of children 68.09 (enough), and cycle III results of $91.4 \%$ of children's learning outcomes (Very Good Developing) with an average of 82.9 (good). The increase in cycle III occurs when the use of fruit puzzle media is accompanied by singing method while writing numbers. Children will get the experience of writing numbers concretely through the song "numbers". So that in this case the child memorizes the form from the symbol number 1 to 10.
\end{abstract}

Keywords: Ability to Know Numbers Symbols 1-10, Numbers Puzzle Fruit Media
Abstrak: Penelitian ini dilatarbelakangi oleh kemampuan mengenal lambang bilangan 1-10 pada Raudlatul Athfal Babussalam rendah. Hal ini terbukti dengan hasil belajar siswa yang menunjukan $78,26 \%$ anak belum mengenal lambang bilangan 1-10 pada rentang usia 4-5 tahun.Penelitian ini bertujuan untuk mengetahui proses pembelajaran mengenal lambang bilangan 1-10 pada Kelompok A Di Raudlatul Athfal Babussalam, Krian, Sidoarjo dengan 
menggunakan media buah Puzzle angka. Serta untuk mengetahui peningkatan kemampuan mengenal lambang bilangan 1-10 pada Kelompok A Di Raudlatul Athfal Babussalam, Krian, Sidoarjo melalui penggunaan media buah Puzzle angka. Metode yang digunakan dalam penelitian ini adalah penelitian tindakan kelas dengan model Kurt Lewin. Penelitian ini dari Pra Siklus, Siklus I, Siklus II, dan Siklus III. Pada Siklus I, Siklus II, dan Siklus III terdiri dari empat tahap yaitu perencanaan, tindakan, observasi, dan refleksi. Subjek penelitian ini adalah siswa Raudlatul Athfal Kelompok A1 Usia 4-5 tahun dengan jumlah 23 anak. Hasil Penelitian adalah sebagai berikut: 1) Pembelajaran dengan menggunakan media buah Puzzle angka dapat berjalan dengan baik dalam setiap siklus. Hal ini dapat dilihat dari hasil observasi aktivitas guru dan siswa. Hasil aktivitas guru pada siklus I mencapai 78,6\%, (cukup) siklus II 83,4\% (cukup), dan siklus III 92,8\% (baik). Sedangkan hasil observasi aktivitas siswa pada siklus I mencapai 76,2\% (cukup), siklus II 83,4\% (cukup), dan siklus III 94,04\% (sangat baik). 2) Adanya peningkatan kmampuan mengenal lambang bilangan 1-10 setelah adanya pengunaan media buah Puzzle angka. Hal ini dapat terlihat dari hasil ketuntasan belajar anak pada tahap siklus I 39,2\% (Belum Berkembang) dengan rata-rata 50,35 (cukup), siklus II hasil ketuntasan belajar anak 60,9\% (Mulai Berkembang) dengan rata-rata 68,09 (cukup), dan siklus III hasil ketuntasan belajar anak 91,4\% (Berkembang Sangat Baik) dengan rata-rata 82,9 (baik). Peningkatan pada siklus III terjadi saat penggunaan media buah Puzzle angka disertai dengan metode bernyanyi sambil menulis angka. Anak akan mendapat pengalaman menulis angka secara konkrit melalui nyanyian lagu "angka". Sehingga dalam hal ini anak lebih menghafal bentuk dari lambang bilangan 1 sampai dengan 10 .

Kata Kunci: Kemampuan Mengenal Lambang Bilangan 1-10, Media Buah Puzzle Angka

\section{PENDAHULUAN}

Pendidikan Anak Usia Dini pada hakikatnya ialah pendidikan yang diselenggarakan dengan tujuan untuk menfasilitasi pertumbuhan dan perkembangan anak secara menyeluruh atau menekankan pada pengembangan seluruh aspek kepribadian anak (Suyadi \& Ulfa, 2013: 17). Salah satu aspek perkembangan yang mendapat stimulasi dan perhatian khusus di PAUD yakni aspek perkembangan kognitif. Perkembangan kognitif sangat penting dikembangkan pada Taman Kanak-kanak dengan tujuan megembangkan kemampuan berfikir anak dalam mencari alternatif pemecahan masalah dan mengembangkan kemampuan logika matematika.

Kemampuan logika matematika yang dapat dikembangkan di TK antara lain mengenalkan konsep bilangan, beberapa pola, perhitungan, pengukuran, geometri, pemecahan masalah, dan strategi permainan (Sujiono, 2009: 187). Mengenal lambang bilangan penting dikembangkan sebagai dasar kemampuan matematika pada anak (Yustianti, 2016: 97). Pengenalan lambang bilangan akan dapat menstimulasi perkembangan kognitifnya, sehingga anak akan mampu mengolah dan menggunakan lambang bilangan tersebut pada kehidupan sehari-hari (Gendana, 2017: 93). Maka dari itu, pengenalan lambang bilangan pada anak perlu diberikan sejak dini dengan menggunakan cara yang tepat sesuai dengan tahap perkembangan anak.

Berdasarkan hasil observasi dilakukan peneliti di Raudlatul Athfal Babusalam, Krian, Sidoarjo, sekitar 78,26\% dari anak kelompok A memiliki kemampuan mengenal 
lambang bilangan 1-10 mayoritas sangat rendah (Sulisyowati, 2018). Ketika guru meminta anak untuk menunjuk lambang bilangan 1-10 secara acak di papan tulis, mereka masih terlihat bingung dan belum bisa menghafal lambang bilangan dengan baik. Anak mampu melafalkan bilangan 1-10 secara urut dan benar, namun anak belum mampu membedakan bentuk dari lambang bilangan 1-10 dengan baik. Sebagian besar anak masih sulit membedakan bentuk lambang bilangan 1-10 terutama angka 6 dan 9 .

Ada beberapa hal yang menyebabkan kemampuan mengenal lambang bilangan 110 sangat rendah. Media pembelajaran yang digunakan guru saat mengenalkan lambang bilangan 1-10 kurang menarik. Metode yang digunakan guru dalam mengajar juga kurang bervariasi. Peningkatan kemampuan mengenal lambang bilangan 1-10 pada anak usia 45 tahun dapat dikembangkan melalui adanya media pembelajaran. Sedangkan media pembelajaran yang digunakan untuk mengenalkan lambang bilangan 1-10 pada kelompok A adalah media buah Puzzle angka.

Berdasarkan kajian yang sudah dipaparkan, maka peneliti akan memperbaiki proses pembelajaran dengan melakukan penelitian dengan judul "Peningkatan Kemampuan Mengenal Lambang Bilangan 1-10 Melalui Penggunaan Media Buah Puzzle Angka Pada Kelompok A Di Raudlatul Athfal Babussalam, Krian, Sidoarjo". Adapun rumusan masalahnya yaitu bagaimana proses pembelajaran mengenal lambang bilangan 1-10 pada Kelompok A Di Raudlatul Athfal Babussalam, Krian, Sidoarjo dengan menggunakan media buah Puzzle angka? dan bagaimana peningkatan kemampuan mengenal lambang bilangan 1-10 pada Kelompok A Di Raudlatul Athfal Babussalam, Krian, Sidoarjo melalui penggunaan media buah Puzzle angka?

Tujuan dari penelitian ini adalah untuk mengetahui proses pembelajaran mengenal lambang bilangan 1-10 pada Kelompok A Di Raudlatul Athfal Babussalam, Krian, Sidoarjo dengan menggunakan media buah Puzzle angka dan untuk mengetahui peningkatan kemampuan mengenal lambang bilangan 1-10 pada Kelompok A Di Raudlatul Athfal Babussalam, Krian, Sidoarjo melalui penggunaan media buah Puzzle angka. Penelitian ini diharapkan mampu memberikan modal referensi pada dunia pendidikan anak usia dini dalam mengembangkan media pembelajaran, khususnya sebagai pengenalan lambang bilangan 1-10.

Terdapat tiga indikator yang hendak dicapai dalam penelitian ini yaitu menyebutkan bilangan 1-10 dengan menunjuk benda-benda, menunjukkan urutan benda untuk bilangan 1-10, dan menghubungkan atau memasangkan lambang bilangan 1-10 dengan benda-benda.

Pengertian perkembangan kognitif adalah suatu perubahan yang lebih baik dan dialami oleh manusia dalam melakukan akivitas mental yang berhubungan dengan persepsi, pikiran, ingatan, dan pengolahan nformasi yang memungkinkan anak memperoleh pengetahuan, memecahkan masalah ataupun merencanakan masa depan (Desmita, 2013) Perkembangan kognitif anak usia 4-5 tahun telah mampu melakukan beberapa hal yaitu menyebutkan urutan bilangan 1-10, membilang dan menunjuk benda, mengenal konsep banyak-sedikit, lebih-kurang, sama atau tidak sama, menghubungkan lambang bilangan dengan benda, memecahkan masalah sederhana seperti mengerjakan maze, menyusun Puzzle , mencari lokasi asal suara.(Wening, 2012: 162)

Kemampuan mengenal lambang bilangan adalah suatu daya atau kesanggupan yang dimiliki anak sejak dini untuk mengembangkan pengetahuannya dalam belajar matematika yaitu mengenal berbagai angka (lambang bilangan) sesuai dengan tahap perkembangannya dan dapat terus meningkat (Susanto, 2012: 98). Adapun kemampuan mengenal angka atau lambang bilangan melalui beberapa tahap, diantaranya yaitu (1) 
tahap mengenal dan membaca bilangan. Pada tahapan awal mengenal bilangan anak dikenalkan secara lisan atau lewat ucapan. (2) Tahap menulis angka. Setiap angka memiliki keunikan dan perbedaan cara penulisannya. Untuk itu anak perlu dikenalkan dengan cara menuliskan angka dengan benar. (3) Tahap membilang, terdapat dua kegiatan yakni anak menyebut seri bilangan mulai dari angka satu, dan anak dapat menunjuk pada objek yang berbeda sementara ia sedang menghitung (Runtukahu, 2014: 92).

Media pembelajaran anak usia dini adalah segala sesuatu yang dapat dijadikan alat atau bahan untuk belajar dan bermain yang membuat anak memperoleh pengetahuan serta keterampilan dari media pembelajaran tersebut (Latif, 2013: 155). Sedangkan media buah Puzzle angka adalah sarana menyampaikan informasi atau pesan mengenai lambang bilangan 1-10 yang dikemas melalui permainan Puzzle dua keping dengan tema buah untuk anak usia empat sampai dengan lima tahun. Bahan yang digunakan dalam pembuatan media buah Puzzle angka ini berasal dari kertas duplek yang dibungkus dengan kain flannel dengan bentuk buah dan warna yang menarik dan disukai anak.

Cara menggunakan media buah Puzzle angka antara lain:

1. Guru meletakkan media buah Puzzle angka dalam bentuk horizontal dan melepas semua kepingan Puzzle.

2. Guru menempel kartu angka 1-10 secara berurutan pada papan tulis dan meminta anak membacanya secara urut.

3. Anak diminta menyusun kepingan Puzzle hingga membentuk buah jeruk yang utuh.

4. Anak diminta menyebutkan bilangan antara 1-10 dengan media berdasarkan lambang bilangan yang telah ditunjuk guru pada media tersebut.

5. Media diletakkan berbentuk horizontal dengan posisi lambang bilangan 1-10 yang acak.

6. Anak diminta mengurutkan media berdasarkan lambang bilangan 1-10 secara urut.

7. Guru melepas semua kepingan Puzzle dan meletakkan kepingan Puzzle yang bergambar banyak buah pada media, kemudian meletakkan kepingan Puzzle yang begambar lambang bilangan 1-10 secara acak.

Anak diminta mencari kepingan Puzzle yang hilang dengan cara memasangkan Puzzle bergambar lambang bilangan 1-10 sesuai dengan jumlah gambar buah yang tertera pada media atau sebaliknya.

\section{METODE}

Model penelitian tindakan kelas yang dipilih dalam penelitian ini yaitu model Kurt Lewin. Model Kurt Lewin memiliki empat komponen yakni: (1) perencanaan (planning), (2) tindakan (acting), (3) pengamatan (observing), dan (4) refleksi (reflecting) (Sumadoyo, 2013: 39). Adapun hubungan keempat komponen itu dipandang sebagai satu siklus yang dapat digambarkan sebagai berikut: 


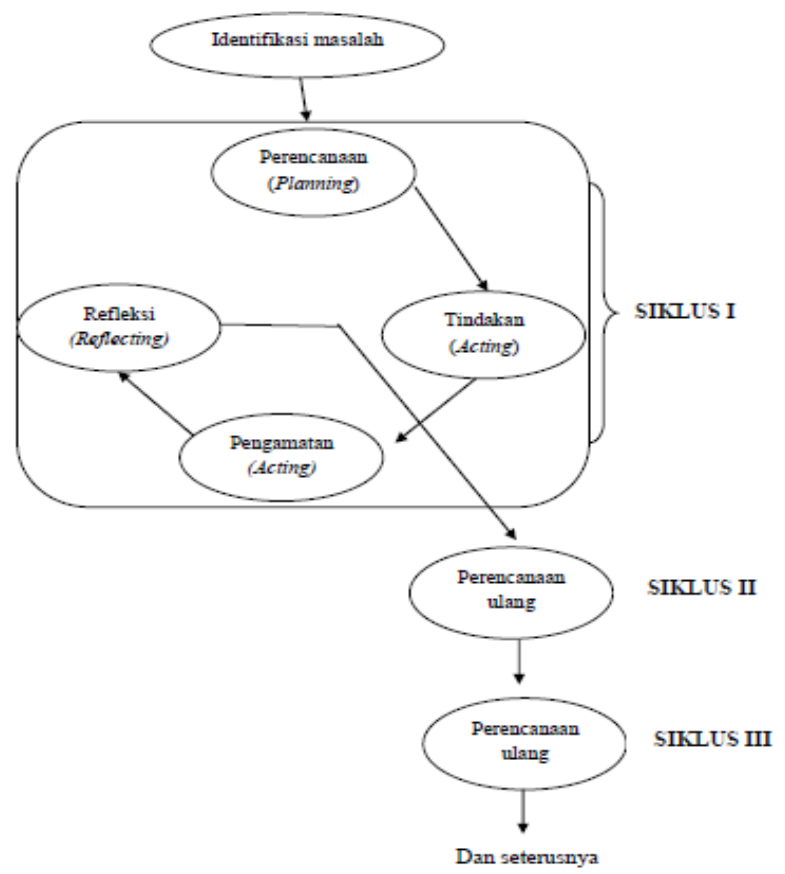

Subjek, lokasi, dan waktu penelitian adalah anak kelompok A1 di Raudlatul Athfal Babussalam, Krian, Sidoarjo, yang terdiri dari 9 laki-laki dan 14 perempuan. Penelitian dilaksanakan pada semester genap tahun ajaran 2017/2018 dalam tiga kali siklus Siklus I dilaksanakan pada tanggal 28, 30, dan 31 Mei 2018. Siklus II dilaksanakan pada tanggal 4, 5, 6 Juni 2018. Sedangkan siklus III dilaksanakan pada tanggal 7, 8, 9 Juni 2018.

Adapun rencana tindakan pada penelitian sebagai berikut:

1. Perencanaan (Planning) yang meliputi penyusunan Rencana Pelaksanaan Pembelajaran Harian (RPPH), mempersiapkan media "Buah Puzzle Angka", menyusun instrumen penelitian yang meliputi pedoman observasi guru dan siswa, mempersiapkan dokumentasi berupa foto dan lembar latihan pengayaan siswa, mempersiapkan instrument penilaian untuk mengukur tingkat kemampuan anak dalam mengenal lambang bilangan 1-10.

2. Pelaksanaan (Acting), guru melaksanakan proses pembelajaran sesuai dengan RPPH dengan menggunakan media buah puzzle angka dan melaksanakan penilaian pada setiap siklus. Adapun pembeda dalam setiap siklus yakni pada siklus II terdapat kegiatan bernyanyi lagu angka. Sedangkan pada siklus III terdapat kegiatan bernyanyi lagu angka disertai dengan menulis angka.

Syair Lagu "Angka"

Satu itu garis lurus

Dua itu lengkung tidur

Tiga itu lengkung-lengkung

Empat miring, tidur, lengkung

Lima lurus, lengkung, tidur

Enam itu miring lengkung

Tujuh itu tidur miring

Delapan itu telur bertingkat

Sembilan lengkung, lurus, lengkung

Sepuluh itu garis lurus telur 
3. Pengamatan (Observing) berlangsng ketika pembelajaran berlangsung dengan mengamati aktivitas guru dan siswa, serta mengamati kemampuan siswa dalam mengenalkan lambang bilangan 1-10.

4. Refleksi (Reflecting), Peneliti melakukan evaluasi dengan melihat seberapa jauh tindakan yang telah dilakukan dapat meningkatkan pembelajaran, serta mengevaluasi kendala dan kelemahan yang dialami selama pelaksanaan siklus agar dapat mengetahui bagaimana langkah menyempurnakannya. Penelitian dikatakan berhasil apabila nilai rata-rata kelas mencapai $\geq 70 \%$, prosentase ketuntasan belajar siswa mencapai $\geq 70 \%$, serta penilaian aktivitas guru dan siswa mencapai $\geq 85 \%$.

Teknik pegumpulan data yang diambil dalam penelitian ini adalah teknik observasi, penilaian, dan dokumentasi.

Tabel 1. Indikator, Jumlah Tes, Bentuk Tes Kemampuan Mengenal Lambang Bilangan 1-10.

\begin{tabular}{|l|l|l|}
\hline \multicolumn{1}{|c|}{ Indikator } & \multicolumn{1}{|c|}{ Jumlah Tes } & \multicolumn{1}{c|}{ Bentuk Tes } \\
\hline $\begin{array}{l}\text { (1)Menyebutkan bilangan 1-10 dengan } \\
\text { menunjuk benda-benda }\end{array}$ & 10 butir soal & Lisan \\
\hline $\begin{array}{l}\text { (2)Menunjukkan urutan benda untuk } \\
\text { bilangan 1-10 }\end{array}$ & 10 butir soal & Lisan \\
\hline $\begin{array}{l}\text { (3)Menghubungkan atau bilangan 1-10 } \\
\text { dengan benda-benda memasangkan } \\
\text { lambang }\end{array}$ & 6 butir soal & $\begin{array}{l}\text { Menjodohkan atau } \\
\text { memasangkan (Tulis) }\end{array}$ \\
\hline
\end{tabular}

Tabel 2. Kisi-kisi Penilaian Mengenal Lambang Bilangan 1-10

\begin{tabular}{|c|c|l|}
\hline $\begin{array}{c}\text { Indik } \\
\text { ator }\end{array}$ & $\begin{array}{c}\text { Sk } \\
\text { or }\end{array}$ & \multicolumn{1}{|c|}{ Keterangan } \\
\hline \multirow{3}{*}{$(1)$} & 1 & $\begin{array}{l}\text { Anak mampu menyebutkan bilangan 1-10 dengan kartu angka tapi masih } \\
\text { terdapat 7-10 soal yang salah. }\end{array}$ \\
\cline { 2 - 3 } & 2 & terdapat 4-6 soal yang salah. \\
\cline { 2 - 3 } & 3 & terdapat 1-3 soal yang salah. \\
\cline { 2 - 3 } & 4 & Benar semua \\
\hline \multirow{5}{*}{$(2)$} & 1 & $\begin{array}{l}\text { Anak mampu menunjukkan urutan lambang bilangan 1-10 melalui kartu } \\
\text { angka tapi masih terdapat 7-10 soal yang salah. }\end{array}$ \\
\cline { 2 - 4 } & 2 & terdapat 4-6 soal yang salah. \\
\cline { 2 - 4 } & 3 & terdapat 1-3 soal yang salah. \\
\cline { 2 - 3 } & 4 & Benar semua \\
\hline \multirow{5}{*}{$(3)$} & 1 & $\begin{array}{l}\text { Anak mampu menghubungkan atau memasangkan lambang bilangan 1-10 } \\
\text { dengan jumlah gambar yang sesuai tapi masih terdapat 5-6 soal yang salah. }\end{array}$ \\
\cline { 2 - 3 } & 2 & terdapat 3-4 soal yang salah. \\
\cline { 2 - 3 } & 3 & terdapat 1-2 soal yang salah. \\
\cline { 2 - 3 } & 4 & Benar semua \\
\hline
\end{tabular}


Teknik analisa data yang digunakan dalam penelitian ini menggunakan metode kualitatif dan kuantitatif. Analisis data kuantitatif dilakukan dengan cara menghitung:

1. Nilai rata-rata kelas

$\mathrm{Me}=\sum \mathbf{x} \sum \mathbf{N} \quad$...Rumus 1

\begin{tabular}{|c|}
\hline \multicolumn{1}{|c|}{ Keterangan: } \\
$\mathrm{M}=$ Rata-rata (Mean) \\
$\sum \mathrm{x}=$ Jumlah semua skor \\
$\sum \mathrm{N}=$ Jumlah anak dalam kelas \\
\hline
\end{tabular}

2. Nilai ketuntasan belajar anak

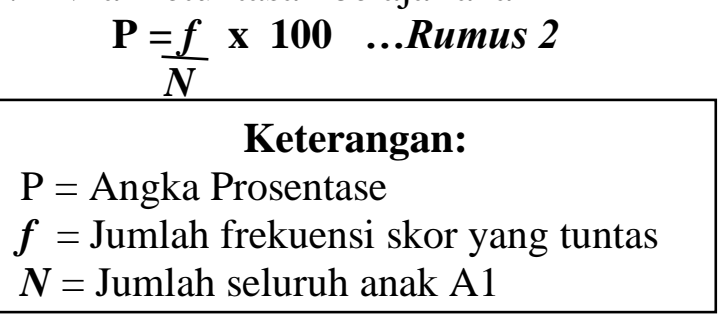

3. Nilai aktivitas guru dan siswa

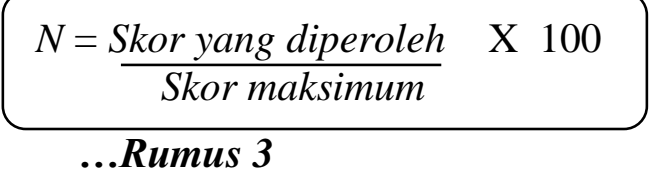

\section{HASIL PENELITIAN DAN ANALISIS}

\section{Kegiatan Pembelajaran Dengan Penggunaan Media Buah Puzzle Angka Untuk Meningkatkan Kemampuan Mengenal Lambang Bilangan 1-10}

Berdasarkan hasil penelitian yang telah dilakukan, menyebutkan bahwasannya motivasi belajar sangat diperlukan sebagai semangat belajar untuk anak. Hal ini sesuai dengan prinsip motivasi dalam belajar yang diungkapkan oleh Mohammad Surya, yakni para siswa harus senantiasa didorong untuk berusaha sesuai dengan tuntutan belajar (Surya, 2004: 63). Sehingga tujuan motivasi belajar disini yakni menumbuhkan kepuasan belajar dalam diri anak. Adapun reaksi kepuasan belajar dalam diri anak ditunjukkan ketika ia tetap berusaha menggunakan buah Puzzle angka meskipun mengalami kegagalan dan terus mencoba hingga pada akhir dilakukannya siklus.

Hadirnya media buah Puzzle angka dalam materi kemampuan mengenal lambang bilangan 1-10 dinilai sangat tepat dilakukan ketika kemampuan anak mengenal lambang bilangan 1-10 rendah. Hal ini sesuai dengan pendapat Boove, bahwasannya media dapat diartikan sebagai alat yang berfungsi untuk menyampaikan pesan pembelajaran (Sanaky, 2013: 3). Media buah Puzzle angka diharapkan mampu meningkatkan kemampuan anak dalam mengenal lambang bilangan 1-10. Hal ini terbukti dari hasil kemampuan belajar anak dari masing-masing siklus yang menunjukkan peningkatan belajar.

Peran guru dalam menerapkan beberapa strategi dalam mengajar selama proses penelitian dinilai sangat efektif. Beberapa strategi yang dilakukan oleh guru meliputi:

a. Desain kegiatan pembelajaran yang bervariasi membuat anak merasa tidak bosan dalam belajar. Kegiatan pembelajaran disesuaikan dengan karakteristik dan tingkat usia anak. Salah satunya yaitu, mewarnai, menggunting, mozaik, membentuk, dan menggambar bentuk buah sederhana agar anak dapat melakukannya secara mandiri. 
Hal ini sesuai dengan pendapat Idad Suhada, bahwasannya peran guru yang hendaknya memberikan kesempatan pada anak untuk belajar sendiri tanpa bantuan guru agar anak dapat belajar secara maksimal (Suhada, 2016: 131).

b. Adanya bentuk kegiatan pembelajaran dengan metode penugasan yang membuat anak lebih fokus dan kondusif terlebih saat proses penggunaan media buah Puzzle angka. Hal ini sesuai dengan pendapat Ali Mudlofir, yakni metode penugasan dapat membina tanggung jawab, disiplin, dan kemandirian diluar pengawasan guru (Mudlofir \& Rosyidah, 2017: 120).

c. Adanya metode bernyanyi yang dapat mengingatkan anak tentang bentuk-bentuk angka 1-10. Hal ini sesuai dengan pendapat Fadlillah yakni, melalui bernyanyi dapat menumbuhkan daya tarik dalam pembelajaran dan sebagai jembatan dalam mengingat materi pembelajaran (Fadlillah, 2014: 44). Hal ini juga terbukti ketika adanya metode bernyanyi pada siklus II, anak lebih siap menerima pembelajaran dan lebih menghafal bentuk angka meskipun tidak secara keseluruhan.

d. Adanya metode bernyanyi sambil menulis yang dapat mengenalkan anak pada pengetahuan angka secara konkrit. Hal ini sesuai dengan Ahmad Susanto, bahwasannya menulis merupakan kegiatan mencurahkan gagasan melalui simbolsimbol tertulis (Susanto, 2012: 91). Pengalaman menulis angka 1-10 ini mampu membuat anak lebih lama mengingat bentuk-bentuk angka.

2. Kemampuan Mengenal Lambang Bilangan 1-10 Melalui Penggunaan Media Buah Puzzle Angka Mengalami Hasil Yang Berbeda Pada Setiap Siklus

a. Observasi Aktivitas Guru dan Siswa

1) Perbandingan Hasil Observasi Guru

Diagram 1

Perbandingan Hasil Observasi Guru

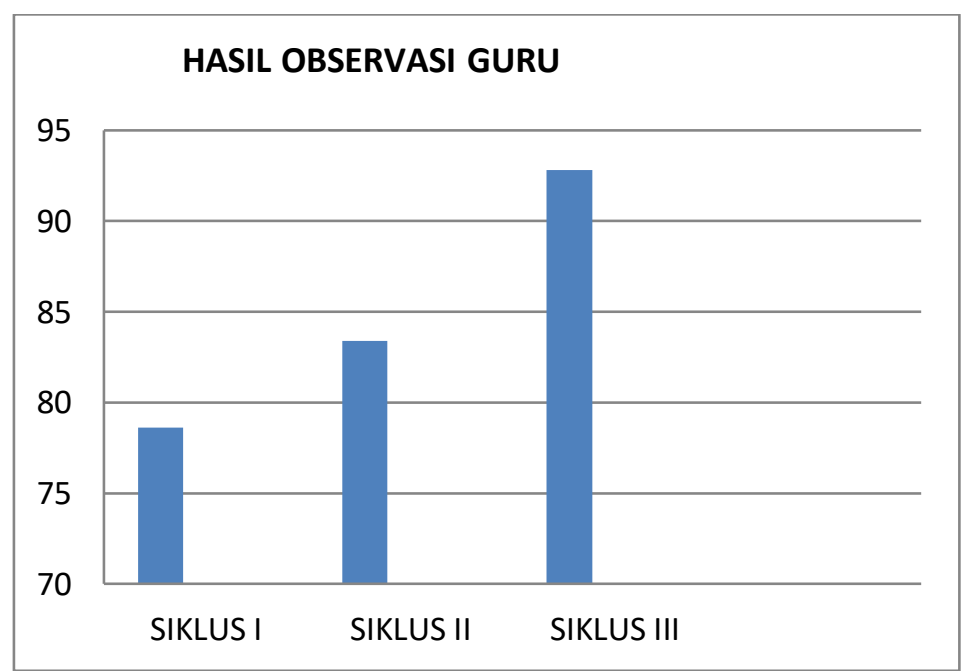

Dari diagram diatas dapat diketahui bahwasannya observasi akivitas guru mengalami peningkatan pada setiap siklusnya. Siklus I memperoleh nilai 78,6\% (cukup), siklus II 83,4\% (cukup), dan siklus III 92,8\% (baik). 
2) Perbandingan Hasil Observasi Siswa

Diagram 2

Perbandingan Hasil Observasi Siswa

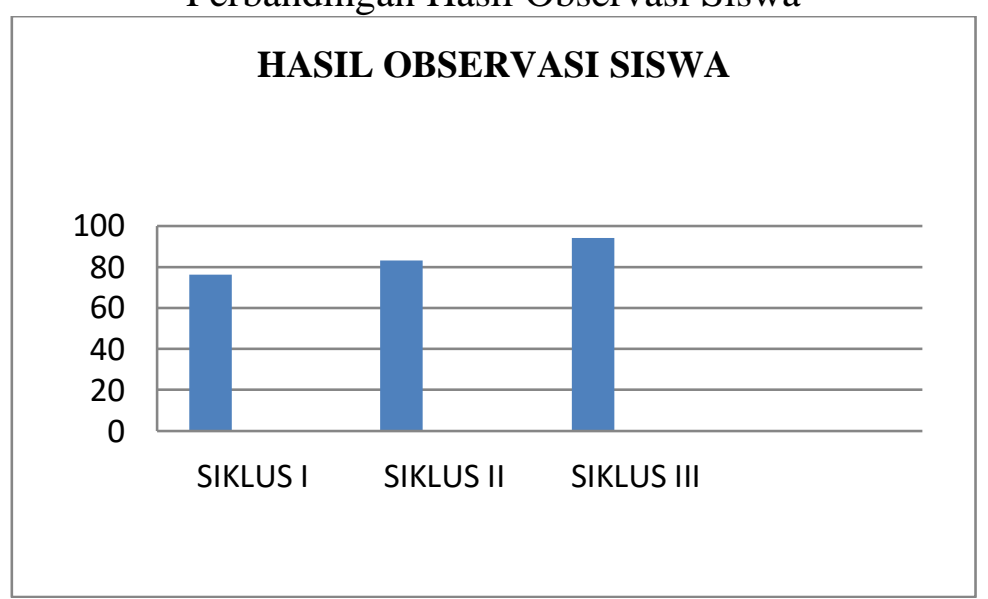

Dari diagram diatas dapat diketahui bahwasannya observasi akivitas siswa mengalami peningkatan pada setiap siklusnya. Siklus I memperoleh nilai 76,2\% (cukup), siklus II 83,4\% (cukup), dan siklus III 94,04\% (sangat baik).

b. Peningkatan Hasil Kemampuan Mengenal Lambang Bilangan 1-10

Penelitian Tindakan Kelas dalam rangka peningkatan mengenal lambang bilangan 1-10 mendapatkan hasil yang baik dari mulai pra siklus, siklus I, siklus II, hingga siklus III. Berikut ini merpakan uraian hasil kemampuan mengenal lambang bilangan 1-10 dari masing-masing siklus.

\section{1) Tahap Pra Siklus}

Diagram 3

Hasil Kemampuan Mengenal Lambang Bilangan 1-10 Pada Tahap Pra Siklus

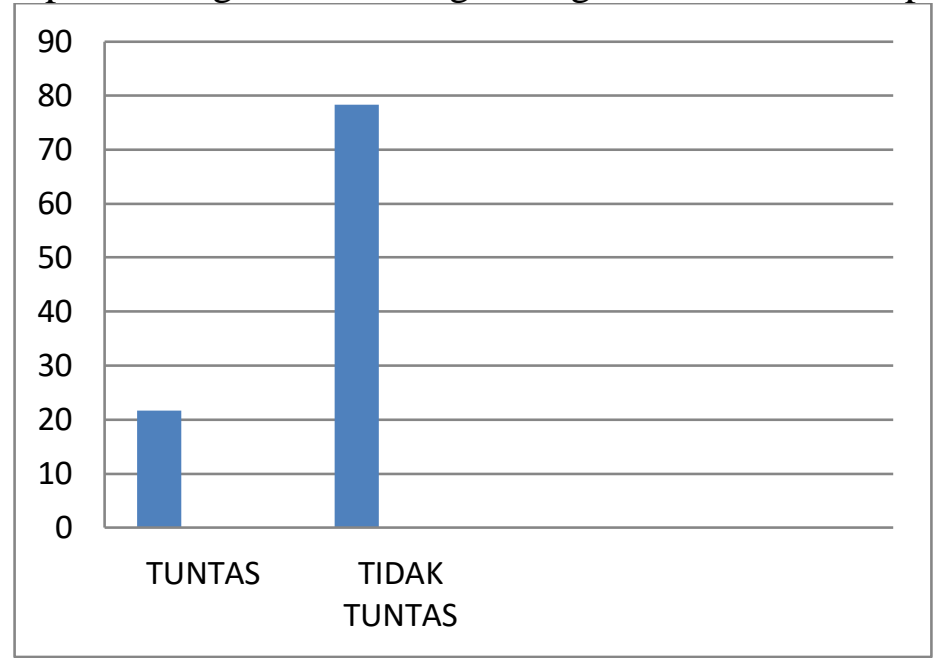

Berdasarkan hasil pengamatan yang dilakukan, kemampuan mengenal lambang bilangan 1-10 pada kelompok A1 ini rendah. Hanya terdapat 5 dari 23 anak yang tuntas dalam kemampuan mengenal lambang bilangan 1-10 atau hanya ada 21,74\%, dan ada $78,26 \%$ anak belum mendapatkan nilai ketuntasan belajar sesuai dengan kriteria penilaian yang ditetapkan guru.

Hasil kemampuan mengenal lambang bilangan 1-10 rendah karena minimnya dana untuk menciptakan media pembelajaran, metode yang digunakan kurang bervariasi, serta kurangnya motivasi belajar yang diberikan oleh guru.

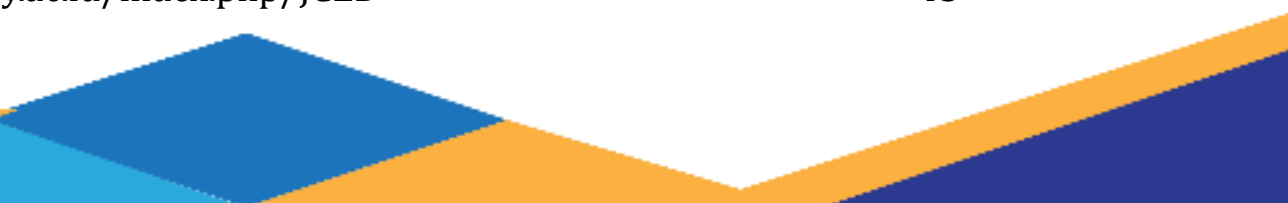




\section{2) Tahap Siklus I}

\section{Diagram 4}

Hasil Kemampuan Mengenal Lambang Bilangan 1-10 Pada Tahap Siklus I

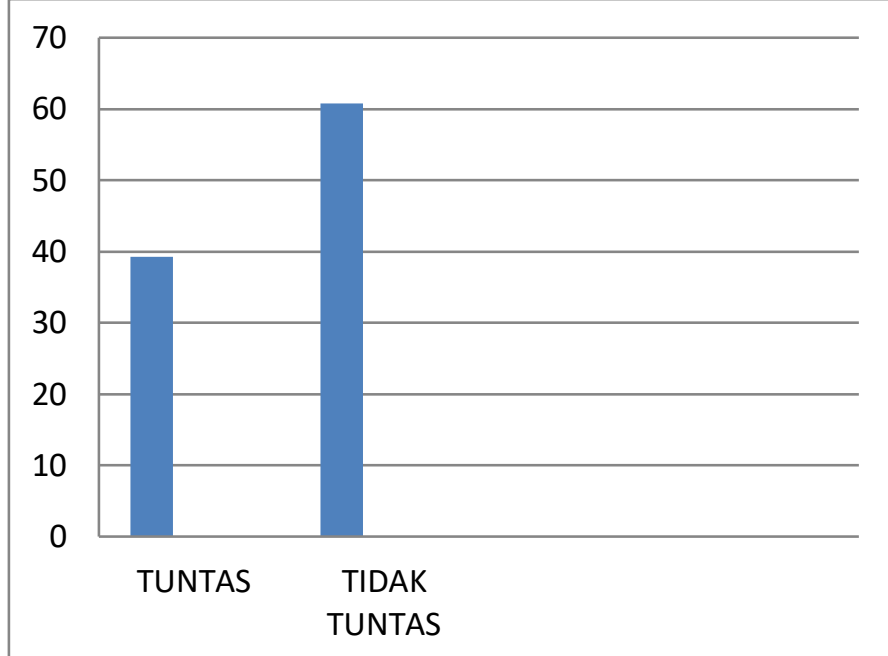

Pada siklus I pembelajaran mulai menggunakan media buah puzzle angka dan memberikan motivasi belajar. Adapun hasil kemampuan mengenal lambang bilangan 110 mengalami peningkatan dari tahap pra siklus ke tahap siklus I. Diketahui terdapat 9 dari 23 anak yang tuntas dalam belajar mengenai kemampuan mengenal lambang bilangan 1-10. Anak yang tuntas mencapai 39,2\% dan yang tidak tuntas 60,9\%.

\section{3) Tahap Siklus II}

Diagram 5

Hasil Kemampuan Mengenal Lambang Bilangan 1-10 Pada Tahap Siklus II

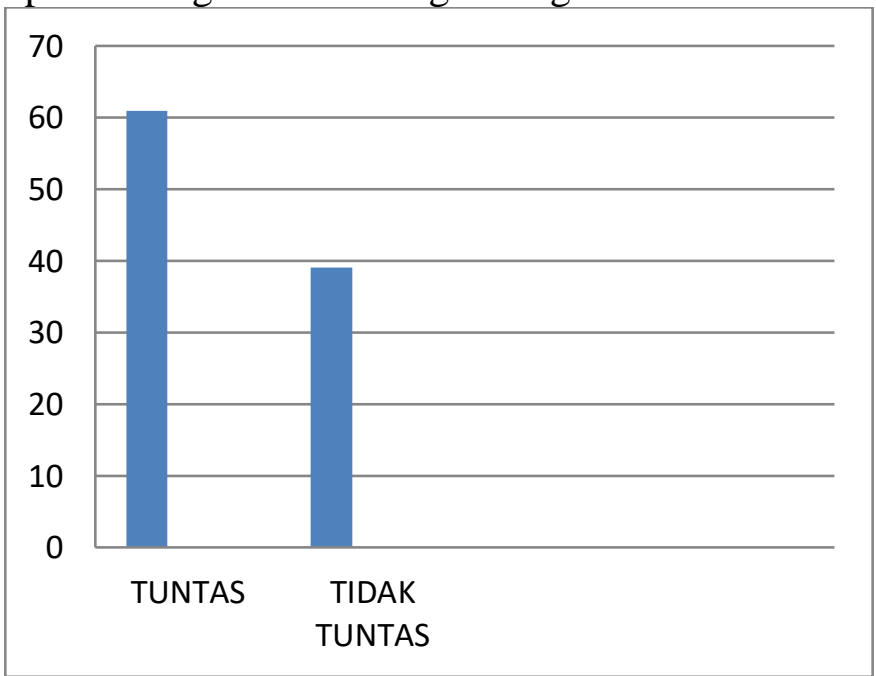

Pada siklus II ini peneliti menambahkan metode bernyanyi lagu "angka" untuk mengenalkan lambang bilangan 1-10 pada anak. Peneliti juga berusaha menjalin kedekatan dengan anak agar terjadinya kenyamanan dalam belajar. Selain itu untuk menjaga kekondusifan kelas, peneliti berusaha membuat beberapa peraturan yang harus dipatuhi selama proses belajar. Adapun hasil yang didapat yakni mengalami peningkatan dari tahap siklus I. Diketahui terdapat 14 dari 23 anak yang tuntas dalam belajar mengenai kemampuan mengenal lambang bilangan 1-10. Adapun presntase ketuntasan sebesar $60,9 \%$ dan yang tidak tuntas $39,1 \%$.

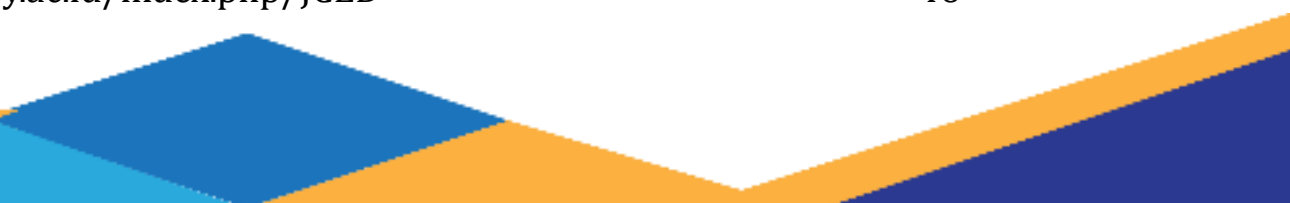




\section{4) Tahap Siklus III}

\section{Diagram 6}

Hasil Kemampuan Mengenal Lambang Bilangan 1-10 Pada Tahap Siklus III

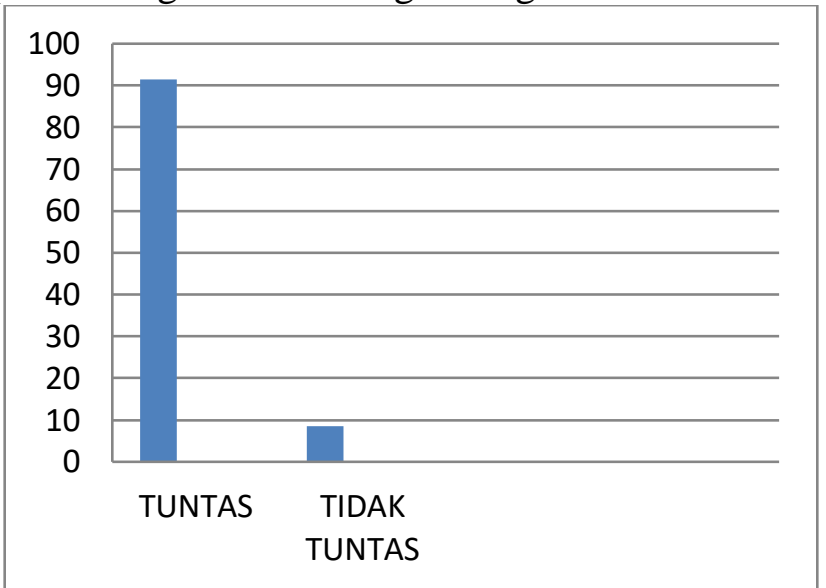

Pada siklus III ini peneliti menggunakan desain pembelajaran yang lebih membuat anak lebih fokus pada kegiatan yang mereka kerjakan. Kegiatan tersebut adalah kegiatan menggunting dan mencetak gambar buah. Selain itu peneliti pada siklus III ini lebih menfokuskan pada pengenalan angka melalui metode menulis. Sehinga anak lebih hafal tentang apa yang mereka tulis dari pada apa yang mereka amati. Adapun hasil yang diperoleh yakni terdapat 21 dari 23 anak yang tuntas dalam belajar mengenai kemampuan mengenal lambang bilangan 1-10. Adapun jumalah presentase ketuntasan sebesar $91,4 \%$ dan siswa tidak tuntas $8,6 \%$.

\section{5) Perbandingan Hasil Kemampuan Mengenal Lambang Bilangan 1-10 Setiap Siklus}

Diagram 7

Perbandingan Hasil Kemampuan Mengenal Lambang Bilangan 1-10 Pada Tahap Pra Siklus, Siklus I, Siklus II, dan Siklus III

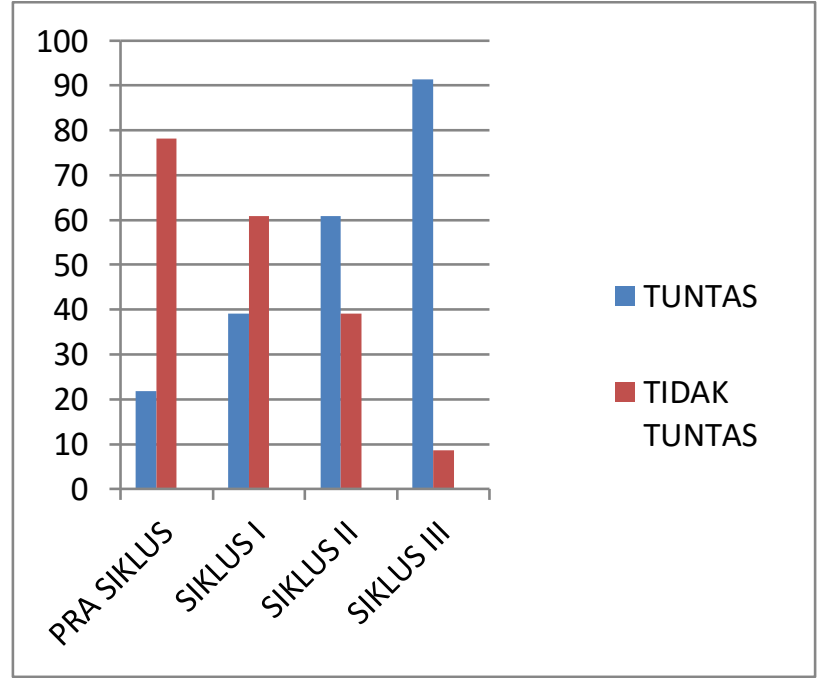

Dari hasil diagram diatas, dapat diketahui kemampuan mengenal lambang bilangan 1-10 mengalami peningkatan dari setiap siklus. Pada tahap pra siklus terdapat 5 orang yang tuntas belajar, siklus I terdapat 9 orang, siklus II terdapat 14 orang, dan siklus III menjadi 21 orang. Sedangkan hasil presentase ketuntasan belajar ketika tahap pra siklus mencapai $21,74 \%$, pada siklus I meningkat menjadi $39,2 \%$, siklus II menjadi 60,9\%, dan siklus III 
menjadi 91,4\%. Pada penelitian ini, tahap pra siklus menuju tahap siklus I mengalami peningkatan sebesar $17,46 \%$, siklus II sebesar $21,7 \%$, dan siklus III sebesar 30,5\%

\section{SIMPULAN}

Berdasarkan hasil penelitian dan pembahasan tentang peningkatan kemampuan mengenal lambang bilangan 1-10 melalui media buah Puzzle angka pada kelompok A di Raudlatul Athfal Babussalam, Krian, Sidoarjo, maka dapat ditarik kesimpulan sebagai berikut:

1. Penggunaan media buah Puzzle angka dilaksanakan anak secara individu. Pembelajaran melalui penggunaan media buah Puzzle angka dalam rangka mengenalkan lambang bilangan 1-10 dilaksanakan dengan disertai kegiatan pembelajaran yang bervariasi, seperti mewarnai, mozaik, mencetak, menggunting, dan menggambar buah sederhana. Hal ini bertujuan untuk menjaga suasana kelas agar tetap kondusif pada saat proses penggunaan media buah Puzzle angka. Pembelajaran akan ditambahkan dengan bernyanyi lagu "angka" yang disertai dengan penulisannya. Melalui pengalaman bernyanyi sambil menulis angka membuat anak lebih menghafal bentuk dari lambang bilangan 1-10.

2. Kemampuan mengenal lambang bilangan 1-10 pada saat penggunaan media buah Puzzle angka mengalami peningkatan dari setiap siklus. Hal ini dapat terlihat dari hasil ketuntasan belajar anak pada tahap siklus I 39,2\% (Belum Berkembang) dengan rata-rata 50,35 (cukup), siklus II 60,9\% (Mulai Berkembang) dengan rata-rata 68,09 (cukup), dan siklus III 91,4\% (Berkembang Sangat Baik) dengan rata-rata 82,9 (baik). Selain itu dapat dilihat dari hasil observasi aktivitas guru dan siswa. Hasil aktivitas guru pada siklus I mencapai 78,6\%, (cukup) siklus II 83,4\% (cukup), dan siklus III $92,8 \%$ (baik). Sedangkan hasil observasi aktivitas siswa pada siklus I mencapai 76,2\% (cukup), siklus II 83,4\% (cukup), dan siklus III 94,04\% (sangat baik).

\section{AKNOWLEDGMENT}

Peneleitian ini di dukung oleh RA Babussalam Krian Sidoarjo.

\section{DAFTAR RUJUKAN}

Desmita. (2013). Psikologi Perkembangan. Bandung: Remaja Rosdakarya.

Fadlillah. (2014). Pendidikan Anak Usia Dini. Jakarta: Prenada Media Group.

Gendana, G. (2017). Peningkatan Pengenalan Lambang Bilangan 1-10 Melalui Media Balok Cuisenaire Pada Anak Usia 4-5 Tahun Di TK At-Toyyibah. Jurnal PAUD Agapedia, 1(1).

Latif, M. (2013). Orientasi Baru Pendidikan Anak Usia Dini. Jakarta: Kencana.

Mudlofir, A., \& Rosyidah, E. F. (2017). Desain Pembelajaran Inovatif. Jakarta: Raja Grafindo Persada.

Runtukahu, T. (2014). Pembelajaran Matematika Dasar Bagi Anak Berkesulitan Belajar. Yogyakarta: Ar-Ruzz Media.

Sanaky, H. (2013). Media Pemelajaran Interatif Inovatif. Yogyakarta: Kaukaba

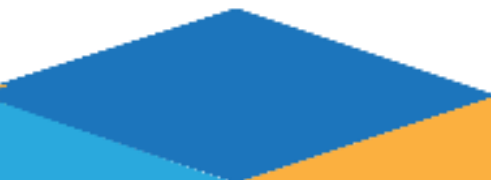


Dipantara.

Suhada, I. (2016). Psikologi Perkembangan Anak Usia Dini. Bandung: Remaja Rosdakarya.

Sujiono, Y. N. (2009). Konsep Dasar PAUD. Jakarta: PT Indeks.

Sulisyowati, A. (2018). Wawancara. Siadorjo.

Sumadoyo, S. (2013). Penelitian Tindakan Kelas. Yogyakarta: Graha Ilmu.

Surya, M. (2004). Psikologi Pembelajaran \& Pengajaran. Bandung: Pustaka Bani Quraisy.

Susanto, A. (2012). Perkembangan Anak Usia Dini: Pengantar Dalam Berbagai Aspeknya. Jakarta: Kencana.

Suyadi, \& Ulfa, M. (2013). Konsep Dasar PAUD. Bandung: Remaja Rosdakarya.

Wening. (2012). Bunda Sekolah Pertamaku. Solo: Tinta Medina.

Yustianti. (2016). Meningkatkan Kemampuan Mengenal Lambang Bilangan Melalui Bermain Kartu Angka Bergambar Pada Anak Usia TK. Jurnal PAUD.

\section{AUTHOR}

Alfiatul Izzati Irawan, merupakan Guru RA Babussalam Krian Sidoarjo 